American Journal of Biochemistry and Biotechnology 6 (4): 284-299, 2010

ISSN 1553-3468

(C) 2010 Science Publications

\title{
Effect of Plant Growth Regulators on Callus, Cell Suspension and Cell Line Selection for Flavonoid Production from Pegaga (centella asiatica L. urban)
}

\author{
${ }^{1,3}$ Suat Hian Tan, ${ }^{1}$ Radzali Musa, ${ }^{2}$ Arbakariya Ariff and ${ }^{1}$ Mahmood Maziah \\ ${ }^{1}$ Department of Biochemistry, ${ }^{2}$ Department of Bioprocess Technology, \\ Faculty of Biotechnology and Biomolecular Sciences, \\ Universiti Putra Malaysia, 43400 UPM Serdang, Selangor Darul Ehsan, Malaysia \\ ${ }^{3}$ Department of Biotechnology, Faculty of Applied Sciences, \\ University College Sedaya International, 56000, Cheras, Selangor Darul Ehsan, Malaysia
}

\begin{abstract}
Problem statement: Considering pegaga medicinal properties and over-exploitation, the requirement for a tissue culture technique as an alternative production system was crucial. Approach: Investigation of cell suspension culture response to different plant growth regulators (PRGs) for flavonoid production from elite cell line was carried out. Callus cultures were initiated from the leaf explants of Centella asiatica on Murashige and Skoog (MS) medium containing B5 vitamins and $30 \mathrm{~g}$ $\mathrm{L}^{-1}$ sucrose supplemented with different concentrations $\left(0.5-2.5 \mathrm{mg} \mathrm{L}^{-1}\right)$ of 2,4-D, NAA, Dicamba, Picloram and IBA supplied singly and in combination with different concentrations $\left(0.5-1.5 \mathrm{mg} \mathrm{L}^{-1}\right)$ of kinetin, BAP and TDZ. Results: Callus induction was observed for all the PGRs tested. The highest callus induction frequency $(86.67 \%)$ was observed in MS medium containing $2.0 \mathrm{mg} \mathrm{L}^{-1}$ 2,4-D while the combination of $2.0 \mathrm{mg} \mathrm{L}^{-1}$ 2,4-D and $1 \mathrm{mg} \mathrm{L}^{-1}$ kinetin in MS medium gave the highest biomass yield $\left(0.27 \mathrm{~g}\right.$ dry weight culture $\left.{ }^{-1}\right)$. This combination was also found to be best for callus proliferation for all the accessions investigated. Among the four accessions tested, UPM03 was found to have the highest biomass yield $\left(0.041 \mathrm{~g}\right.$ DW culture $\left.{ }^{-1}\right)$ and hydrolysed flavonoid content $\left(10.75 \mathrm{mg} \mathrm{g}^{-1} \mathrm{DW}\right)$ after the 12th day of culture. The flavonoids present in the four accessions were quercetin, kaempherol, luteolin and rutin based on High Performance Liquid Chromatography (HPLC) analysis. These results indicated that $C$. asiatica accession UPM03 was the potential elite cell line in mass production of flavonoid, especially luteolin. Coclusions/Recommendations: In the establishment of cell suspension culture, $2 \mathrm{mg} \mathrm{L}^{-1}$ 2,4-D and $1 \mathrm{mg} \mathrm{L}^{-1}$ kinetin were the best PGRs in supporting the cell growth and flavonoid production. This is the first report on the use of PRGs on the establishment of cell suspension cultures in flavonoid production of C. asiatica.
\end{abstract}

Key words: Callus induction, tissue culture, centella asiatica, luteolin, Plant Growth Regulators (PRGs), flavonoid production, elite cell, suspension cultures, controll cells, Dry Weight (DW), Napthaleneacetic Acid (NAA), Plant Growth Regulators (PRGs)

\section{INTRODUCTION}

Flavonoids' are a class of polyphenolic compounds commonly found in plants. There are over 4000 compounds that have been characterized as flavonoids by scientists (Syamsudin et al., 2009; Lentini et al., 2007). Nevertheless, this number is just the tip of the iceberg as scientists nowadays are confident of discovering many more of this class of compounds in the plant kingdom in future. Currently, flavonoids have drawn much interest among researchers and pharmaceutical sectors due to their potential beneficial effects for human health. In addition, flavonoids are the secondary metabolites of plants that cannot be synthesized by humans (Peterson and Dwyer, 1998). They have been reported to have antibacterial, antiviral, anti-allergic, antiplatelet, anti-inflammatory, antitumour and anti-oxidant activities (Hasan et al.,2009; Zainol et al., 2003; Cook and Samman, 1996).

Centella asiatica is a medicinal plant that has been used since prehistoric times. In contrast to other medicinal plants, C. asiatica has been subjected to quite extensive experimental and clinical investigations (Brinkhaus et al., 2000; Supaporn et al., 2010),

Corresponding Author: Mahmood Maziah, Department of Biochemistry, Faculty of Biotechnology and Biomolecular Sciences, Universiti Putra Malaysia, 43400 UPM Serdang, Selangor Darul Ehsan, Malaysia Tel: +603-89466703 Fax: +603-89430913 
particularly in the treatment of leprosy and wound healing which has shown encouraging results (Mato et al., 2009). According to Cheng and Koo (2000), the effect of wound healing may be due to its up-regulation of human collagen I expression that subsequently increases the tensile strength of wounds. C. asiatica is also used as a brain tonic by the Indians (Mohandas et al., 2009). The conventional propagation method of $C$. asiatica, using vegetative cuttings is very slow and it is not adequate to meet the demands of pharmaceutical industries (Nath and Buragohain, 2005). Plant cell cultures are viewed as an attractive source for the production of biologically active compounds as a source of natural food health supplements, which is of importance because of the restrictions imposed on synthetic supplements.

Callus induction of $C$. asiatica has been carried out previously by Nath and Buragohain (2005) and Jacinda et al. (2008). However, both of the published articles were focused on triterpenoid production. No published reports so far are available on the production of flavonoids in the callus as well as cell suspension cultures on such species. Focusing on the importance of plant cell cultures, the objective of this study was to induce callus from different accessions of Centella asiatica for the production of flavonoids. The effects of Murashige and Skoog (MS) medium in combination with different types of plant growth regulators [i.e., 2,4-dichlorophenoxy acetic acid (2,4D), Napthaleneacetic Acid (NAA), 4-Amino-3,5,6trichloropicolinic acid (Picloram), 3,6-dichloro-o-aniscic acid (Dicamba), indole-3-acetic acid (IAA), 3indolebutyric acid (IBA), 6-Benzyl Adenine (BAP), kinetin and Thidiazuron (TDZ)] on callus induction were investigated. In this study, we reported the selection of elite plant material for the production of high quantities of flavonoid from callus culture's of C. asiatica to ensure consistent production of active compounds.

Because of the interesting biological activities of flavonoids and their low content in intact plants, scientists have sought out alternative ways to achieve higher production of flavonoids. Cell cultures not only have a higher rate of metabolism than differentiated plants, but also have shorter biosynthetic cycles (Nay et al., 2010; Chakraborty and Chattopadhyay, 2008). Since plant cell culture systems are relatively easy to manipulate by experimental processes, they could be developed into a large-scale culture where the secondary metabolites could be extracted. This method can supply a continuous and reliable source of natural products. Discoveries of cell culture capability in producing specific medicinal compounds at a rate similar or superior to the intact plants have accelerated in the last few years. For example, the content of salidroside in the suspension culture of Rhodiola sachalenensis is found to be higher than that of fieldgrown plants (Wu et al., 2003). Therefore, this study aimed to establish the cell suspension culture of $C$. asiatica for the determination of its flavonoid content.

\section{MATERIALS AND METHODS}

Plant materials: Four different types of C. asiatica, based on their morphological characteristics and designated as UPM01, UPM02, UPM03 and UPM04, were collected from Peninsular Malaysia and maintained in the glasshouse of University Putra Malaysia (UPM) as described. The nodes were cleaned thoroughly using 2\% (v/v) Decon 90 and then washed under running tap water. Surface sterilization of the nodes was carried out aseptically by immersing in $20 \%$ (v/v) commercial Clorox with two or three drops of Tween 20 for $15 \mathrm{~min}$. Then, the nodes were briefly rinsed with sterile distilled water for five times. They were cultured in the basal Murashige and Skoog (MS) (1962) medium with B5 vitamins (Gamborg et al., 1968), $30 \mathrm{~g} \mathrm{~L}^{-1}$ sucrose, $2.75 \mathrm{~g} \mathrm{~L}^{-1}$ gelrite and $1 \mathrm{mg} \mathrm{L}^{-1}$ kinetin at $\mathrm{pH}$ 5.7. The fully expanded young leaves from in vitro plants were then excised with a sharp blade into approximately $0.7 \times 0.7 \mathrm{~cm}^{2}$ and placed onto the callus induction medium which have been solidified with $2.75 \mathrm{~g} \mathrm{~L}^{-1}$ gelrite.

Callus induction and biomass yield: To study the effects of different Plant Growth Regulators (PRGs) for callus induction, different auxins at different concentrations (0.5-2.5 $\left.\mathrm{mg} \mathrm{L}^{-1}\right)$ viz. 2,4-D, NAA, Dicamba, Picloram and IBA were tested. The auxins were added either singly or in combination with a low level $\left(0.5-1.5 \mathrm{mg} \mathrm{L}^{-1}\right)$ of BAP, kinetin or TDZ into the MS medium supplemented with B5 vitamins and $30 \mathrm{~g}$ $\mathrm{L}^{-1}$ sucrose (known as MS basal medium), prior to autoclaving, except for Dicamba and TDZ. Dicambe and TDZ were heat sensitive and added into the autoclaved medium after filter sterilizing using 0.20 $\mu \mathrm{M}$ cellulose acetate minisart (Sartorius, Germany). The PGR-free MS basal medium was used as the control treatment. One explant per treatment/vial was used. The $\mathrm{pH}$ of the different media was adjusted to 5.7 prior to autoclaving at $121^{\circ} \mathrm{C}$ for $15 \mathrm{~min}$. Thirty replicates per treatment were used and arranged in a completely randomized design.

Explants were incubated at $25^{\circ} \mathrm{C}$ using a $16 \mathrm{~h}$ photoperiod. The number of explants forming calli, the callus morphology and the callus size, as visually 
assessed on a scale were recorded after four weeks of incubation without sub-culture.

Calli were sub-cultured to fresh medium of the same composition for three passages before use for subsequent experiments. Each passage is three weeks. The proliferated calli of each treatment were weighed [i.e., for Dry Weight (DW)] and recorded after one month of sub-culture (after three passages of subculture).

Callus growth measurement: The callus growth curve was performed to identify the suitable day for callus harvesting based on the flavonoid content analysis. A total of $0.50 \pm 0.05 \mathrm{~g}$ of 12 day old leaf-derived calli of accession UPM03 was used and sub-cultured onto the MS basal medium supplemented with $2 \mathrm{mg} \mathrm{L}^{-1}$ 2,4-D and $1 \mathrm{mg} \mathrm{L}^{-1}$ kinetin, which showed the highest callus proliferation rate. The cultures were incubated for $16 \mathrm{~h}$ photoperiods at $25^{\circ} \mathrm{C}$. The growth measurement [i.e., Fresh Weight (FW) and DW) and the flavonoid content of the calli were monitored every two days for 22 days.

Cell line selection: For the selection of the best cell line, the calli were induced from the leaf explants of the four accessions of $C$. asiatica with the MS basal medium supplemented with $2 \mathrm{mg} \mathrm{L}^{-1} 2,4-\mathrm{D}$ and $1 \mathrm{mg}$ $\mathrm{L}^{-1}$ kinetin. The cultures were incubated using $16 \mathrm{~h}$ photoperiods at $25^{\circ} \mathrm{C}$. The calli induced from each explant were carefully separated and sub-cultured in the same media every three weeks. Each treatment contained three replicates and each of them consisted of $0.50 \pm 0.05$ $\mathrm{g}$ of calli. The proliferated calli were weighed ( $\mathrm{FW}$ and DW) and recorded after 12 days of culture since 12 day old calli gave the highest total flavonoid content as shown by the previous experiment. The dry calli were also analysed for their flavonoid content.

Establishment of cell suspension: Two grams of the leaf-derived calli from C. asiatica accession of UPM03, which had been determined as the cell line of greatest potential during cell line selection was added into an MS basal medium supplemented with either auxins or cytokinins. The auxins used were Picloram, 2,4-D and NAA, while the cytokinins used were TDZ, kinetin and BAP at the concentrations of 1,2 and $3 \mathrm{mg} \mathrm{L}^{-1}$ (Nay et al., 2010; Nath and Buragohain, 2005). The cultures were agitated at $110 \mathrm{rpm}$ and incubated using $16 \mathrm{~h}$ photoperiod at $25^{\circ} \mathrm{C}$.

Sieving with a stainless-steel mesh, with a pore size of $750 \mu \mathrm{m}$ was performed after ten days in order to separate the cells from the intact calli. The suspended cells were then filtered through a Buchner funnel using 100 Rundfilter MN615 filter paper (Macherey-Nagel, USA). The fresh weight of the cells was determined before being dried in the oven at $50^{\circ} \mathrm{C}$ until a constant weight was obtained.

Cell suspension growth curve: The growth measurement of the cell was performed to determine the best period for the cell suspension to be used. For the preparation of stock cultures, $10 \mathrm{~mL}$ of the established cells (i.e., 12 day old), was added into 65 $\mathrm{mL}$ of fresh medium in $250 \mathrm{~mL}$ Erlenmeyer flasks. For the preparation of each treatment, the stock cultures were sieved through a stainless steel mesh (pore size $750 \mu \mathrm{m}$ ) and $5 \mathrm{~mL}$ (approximately $0.10 \pm 0.02 \mathrm{~g}$ ) of the cells were then transferred into $20 \mathrm{~mL}$ of fresh liquid medium. To accurately determine the density, $5 \mathrm{~mL}$ inoculum of sieved stock cultures was centrifuged at $10,000 \mathrm{rpm}$ for $15 \mathrm{~min}$ at $4^{\circ} \mathrm{C}$ (Sigma K-20, USA). The supernatant was discarded and the fresh cell weight was determined. In the case where the fresh weight was less than $0.10 \pm 0.02 \mathrm{~g}$, more inoculums were added to achieve the control density. Conversely and if the fresh cell weight was more than $0.10 \pm 0.02 \mathrm{~g}$, some media were discarded after the cells settled down. Five milliliter of inoculum containing $0.10 \pm 0.02 \mathrm{~g}$ fresh cells was then inoculated into $20 \mathrm{~mL}$ of medium in a $100 \mathrm{~mL}$ Erlenmeyer flask. The cell suspension culture was monitored at two-day interval for 26 days. It was repeated three times.

Analysis of flavonoid content: For analysis of the flavonoid content, the extraction and hydrolysis conditions were based on the method described by Crozier et al. (1997). The oven-dried calli were extracted with $10 \mathrm{~mL}$ of $60 \%$ aqueous methanol containing $20 \mathrm{mM}$ sodium diethyldithiocarbamate (NaEDTC) as an antioxidant. They were hormogenized with mortar and pestle before $2.5 \mathrm{~mL} 6 \mathrm{M} \mathrm{HCl}$ was added to each extract to give a $12.5 \mathrm{ml}$ solution of 1.2 $\mathrm{M} \mathrm{HCl}$ in $50 \%$ aqueous methanol. The extracts were refluxed at $90^{\circ} \mathrm{C}$ for two $\mathrm{h}$ and labelled as the hydrolyzed extracts. Meanwhile, the extracts not undergoing reflux were labelled as the unhydrolyzed extracts. The total flavonoid content was determined by using the aluminium chloride colorimetric assay method according to Marinova et al. (2005). Luteolin was used as the standard flavonoid.

For HPLC analysis, the hydrolysed extracts were filtered through a $0.45 \mu \mathrm{m}$ filter (Minisart RC 15, Sartorius, Germany) and analysed using the Waters 
(Milford, MA, USA) liquid chromatograph comprising an empowered chromatography manager, a 717 plus autoinjector, 501 HPLC pump and a 486-tunable absorbance detector. Reverse-phase separations were carried out at room temperature using a $150 \times 3.9 \mathrm{~mm}$ I.D., $4 \mu \mathrm{m} \mathrm{C}_{18}$ Nova-Pak column (Waters). The column was eluted using gradient of $22 \%-35 \%$ acetonitrile in water, adjusted to $\mathrm{pH} 2.5$ with Trifluoroacetic Acid

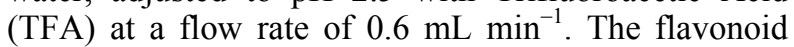
compounds were detected at $365 \mathrm{~nm}$. Identification of each compound was achieved by comparison with the commercial standard. The quantity of flavonoid compounds in each sample was determined from the standard curve.

Statistical analysis: The data were analyzed using oneway ANOVA. The mean values were compared utilising Duncan's multiple range test at $5 \%(p=0.05)$ significance level using SPSS software version 11.5 (SPSS Inc. USA).

\section{RESULTS}

Callus induction and biomass yield: A preliminary experiment was carried out using the fourth and fifth fully older expanded leaves as explants in the callus induction experiment. However, most of the explants cultured with either $1 \mathrm{mg} \mathrm{L}^{-1}$ auxins or without any plant growth regulator began to turn brown after two weeks of culture. Only $10 \%$ of the explants survived and managed to produce calli (data not shown). In order to determine the influence of auxins on callus induction, six auxins, namely; 2,4-D, Picloram, Dicamba, IAA, IBA and NAA, were used.

After a week in the callus induction medium, the explants started to swell. A transition state was observed where small fluffy hairy structures formed before the callus developed. No calli were induced in the MS basal medium without the plant growth regulators (Table 1A), indicating that PGRs are required for callus induction. Maximum callusing $(83.33 \%)$ was noticed on the leaf explants grown on MS basal medium supplemented with $1 \mathrm{mg} \mathrm{L}^{-1}$ 2,4-D. Most of the calli were found covering the surface of the explants and they were friable and whitish green.

The auxin NAA was poor in inducing callus from C. asiatica. It only produced a $46.8 \%$ of callus response. NAA treatment also resulted in adventitious roots. In addition, the morphology of the calli obtained was distinctly different from the treatment with 2,4-D, producing white friable textures.

Table 1: The callus induction from the leaf explants of C. asiatica inoculated on the MS media supplemented with $1.0 \mathrm{mg} \mathrm{L}^{-1}$ of different types of auxins (A), different concentrations of 2,4-D (B) and $2 \mathrm{mg} \mathrm{L}^{-1}$ of 2,4-D in combination with different concentrations of TDZ, BAP and kinetin (C)

\begin{tabular}{lllll}
\hline $1.0 \mathrm{mg} \mathrm{L}^{-1}$ auxin & Callus score & Explant forming callus (\%) & Callus morphology & $\begin{array}{l}\text { Callus DW after one } \\
\text { month culture (mg culture }^{-1} \text { ) }\end{array}$ \\
\hline MSO & NC & NC & NC & NC \\
2,4-D & +++ & 83.33 & Whitish green, friable & $43.6^{\mathrm{a}}$ \\
Picloram & ++ & 43.7 & Pale whitish, friable & $30.3^{\mathrm{b}}$ \\
Dicamba & + & 3.1 & Whitish, friable & $9.8^{\mathrm{e}}$ \\
IBA & + & 37.5 & Whitish, friable & $13.0^{\mathrm{d}}$ \\
NAA & + & 46.8 & Whitish, friable & $18.7^{\mathrm{c}}$ \\
\hline
\end{tabular}

Table 1: (b)

\begin{tabular}{lllll}
\hline $\begin{array}{l}2,4-\mathrm{D} \text { concentration } \\
(\mathrm{mg} / \mathrm{L})\end{array}$ & Callus score & Explant forming callus $(\%)$ & Callus morphology & $\begin{array}{l}\text { Callus DW after one } \\
\text { month culture }\left(\mathrm{mg} \mathrm{culture}^{-1}\right)\end{array}$ \\
\hline 0 & NC & NC & NC & NC \\
0.5 & ++ & 75.00 & Whitish green, friable & $29.0^{\mathrm{d}}$ \\
1.0 & ++ & 83.33 & Whitish green, friable & $44.0^{\mathrm{c}}$ \\
1.5 & +++ & 80 & Whitish green, friable & $69.7^{\mathrm{b}}$ \\
2.0 & +++ & 86.67 & Whitish green, friable & $80.0^{\mathrm{a}}$ \\
2.5 & +++ & 83.33 & Whitish green, friable & $67.0^{\mathrm{b}}$ \\
\hline
\end{tabular}

Table 1: (C)

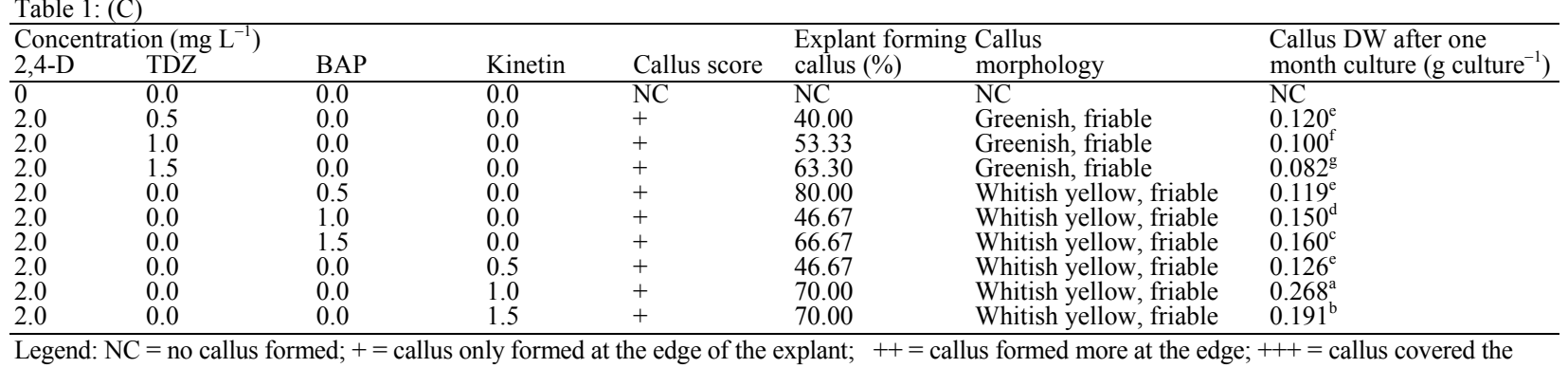


Similarly, IBA was also not very effective in the formation of callus. It showed a low callus induction rate at $37.5 \%$. The callus was friable in texture and white in colour. Besides that, IBA showed a very high performance with respect to adventitious root formation (data not shown). Picloram was a better auxin for callus induction compared to IAA, IBA and Dicamba. Evidently, the response was $43.7 \%$ at $1 \mathrm{mg} \mathrm{L}^{-1}$ picloram treatment and the induced calli were friable whitish pale in colour. The least callus response was observed in dicamba at only $3.1 \%$, the calli were only formed at the cut edge of the leaf explants after 34 days of inoculation. Furthermore, they were friable in texture and white in colour.

Further investigation on callus induction was carried out using 2,4-D ranging from $0.5-2.5 \mathrm{mg} \mathrm{L}^{-1}$ and the result are shown in Table 1B. The callus formation started from the cut margins of the leaf explants after four weeks of inoculation. This study revealed that 0.5 $m g ~^{-1}$ 2,4-D was inadequate for the optimal callus induction from C. asiatica leaf explants. Highly proliferating whitish green calli was observed in the medium supplemented with $2 \mathrm{mg} \mathrm{L}^{-1} 2,4-\mathrm{D}$. In addition, callogenesis was noticed within four weeks, producing

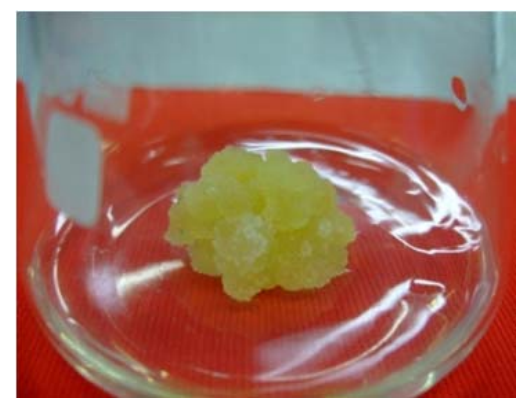

(a)

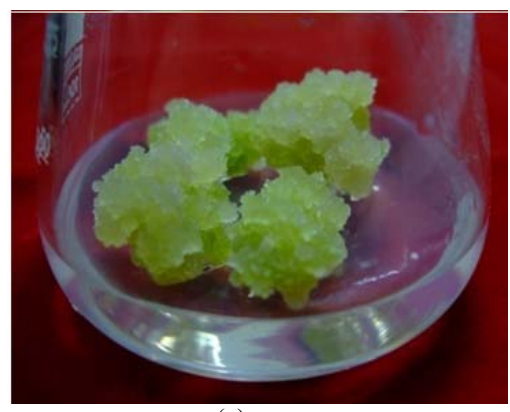

(c) an $86.67 \%$ callus response. The application of $2.5 \mathrm{mg}$ $\mathrm{L}^{-1}$ of 2,4-D was not able to increase the callus efficiency or shorten the period of callogenesis.

A further screening of suitable growth regulators for C. asiatica callus induction was conducted through culturing of young leaf explants on the MS basal medium supplemented with the combination of $2 \mathrm{mg}$ $\mathrm{L}^{-1}$ 2,4-D and different cytokinins, particularly BAP, kinetin and TDZ, in the range of $0.5-1.5 \mathrm{mg} \mathrm{L}^{-1}$ (Table 1C). The calli were found initiated at all the hormone combinations and formed at the edge of the explants. The induction at $2.0 \mathrm{mg} \mathrm{L}^{-1} 2,4-\mathrm{D}$ with $0.5 \mathrm{mg} \mathrm{L}^{-1} \mathrm{BAP}$ produced the highest response, which comprised $80 \%$ of friable whitish yellow calli. Callusing had been achieved after 33 days of culture.

On the other hand, the combination of $2 \mathrm{mg} \mathrm{L}^{-1}$ 2,4-D with low concentration $\left(1.0 \mathrm{mg} \mathrm{L}^{-1}\right)$ of kinetin produced a lower callus induction rate, which was $46.67 \%$. The increment of kinetin concentration had gradually increased the rate of callus induction up to $70 \%$ within one month of culture. However, when 0.5 $\mathrm{mg} \mathrm{L}^{-1}-1.5 \mathrm{mg} \mathrm{L}^{-1}$ of TDZ were applied together with 2 $\mathrm{mg} \mathrm{L}^{-1} 2,4-\mathrm{D}$, it revealed lower induction rates in the range of $40-63.3 \%$. A compact greenish callus formation was observed.

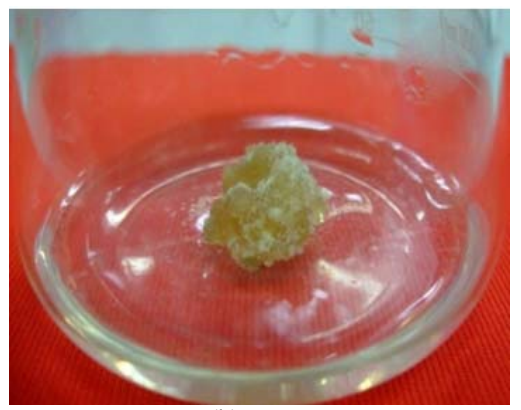

(b)

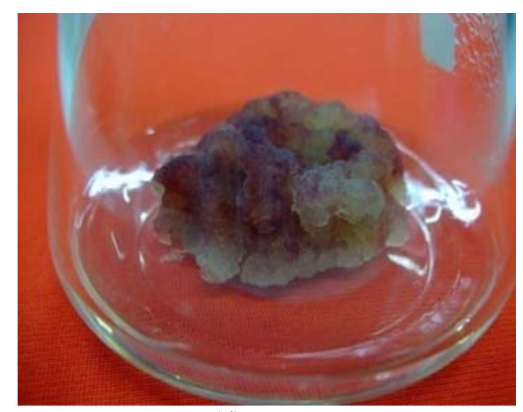

(d)

Fig. 1: The morphology of four weeks old leaf-derived calli of different accessions of C. asiatica. UPM01 (A) UPM02 (B) UPM03 (C) UPM04 (D). They were maintained in the MS basal medium supplemented with 2.0 $\mathrm{mg} \mathrm{L}{ }^{-1} 2,4-\mathrm{D}$ and $1 \mathrm{mg} \mathrm{L}^{-1}$ kinetin incubated at $25^{\circ} \mathrm{C}$ under $16 \mathrm{~h}$ photoperiod. $\mathrm{Bar}=1 \mathrm{~cm}$ 


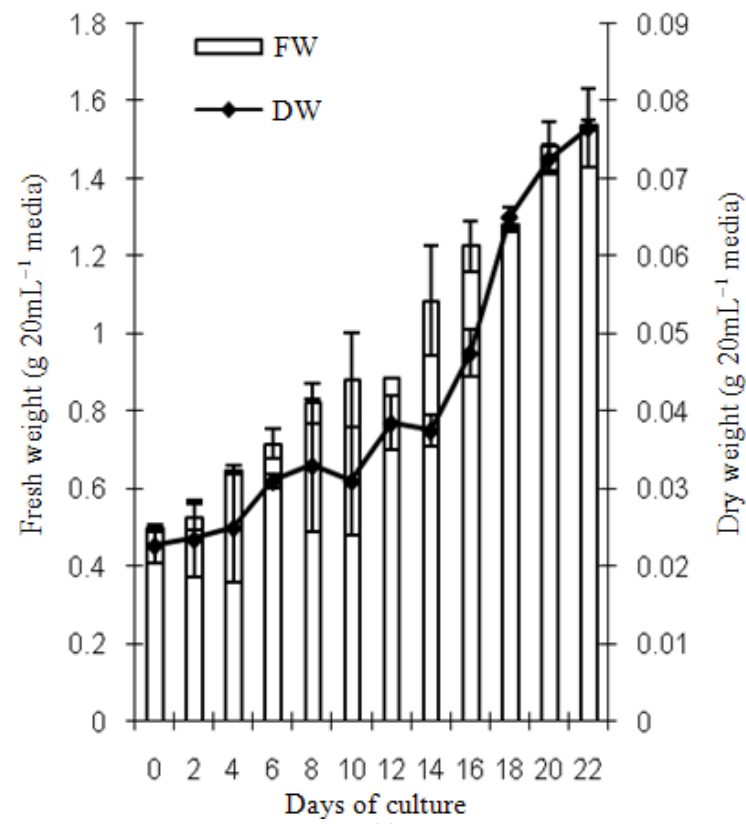

(a)

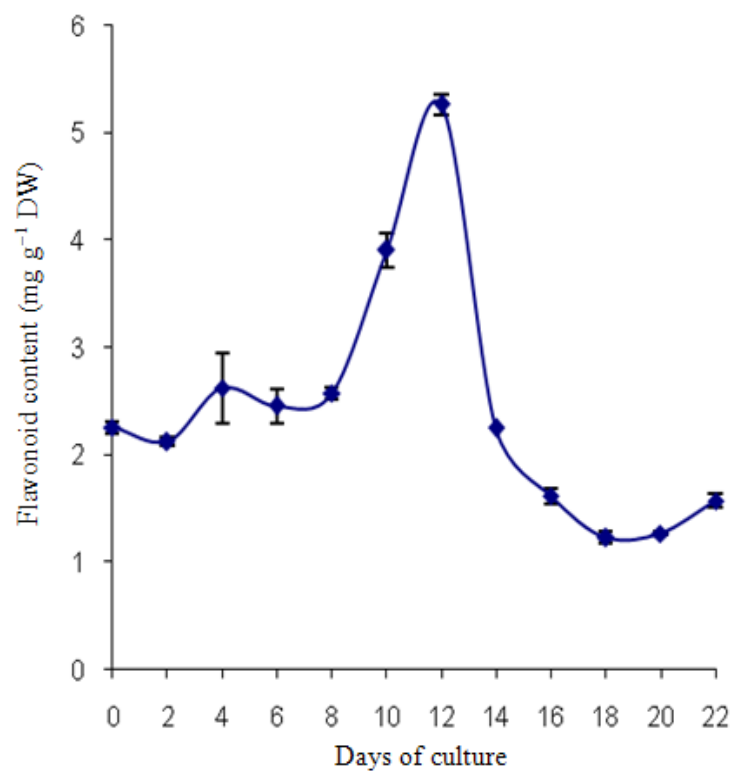

(b)

Fig. 2: The growth curve measurement (A) and the time profile of flavonoid content (B) in C. asiatica accession of UPM03, which was determined every two days after inoculation. Twelve-days old leaf-derived calli cultured on the MS basal medium supplemented with 2,4D: kinetin $(2: 1 \mathrm{mg} / \mathrm{L})$ incubated at $25^{\circ} \mathrm{C}$ under $16 \mathrm{~h}$ photoperiod. The bar indicates the standard deviation of mean $(\mathrm{n}=3)$
Callus biomass yield: In this study, the three weeks old calli with a fresh weight of $0.5 \pm 0.05 \mathrm{~g}$ were subcultured on the MS basal medium with various concentrations of auxins and cytokinins. Table 1A shows that $1 \mathrm{mg} \mathrm{L}^{-1}$ of 2,4-D gave the highest dry weight followed by Picloram, NAA, IBA and Dicamba. Since there was no callus induced from the MS basal medium without hormones (control), there was no dry weight value in this experiment.

A further screening with the concentrations of 0.5 , $1.0,1.5,2.0$ and $2.5 \mathrm{mg} \mathrm{L}^{-1}$ of $2,4-\mathrm{D}$ was carried out (Table 1B). Since there was no callus induced from the MS basal medium without hormones (control), there was no dry weight value in this experiment. Increase of dry weights were observed in the 2,4-D treatment from 0.5 to $2.0 \mathrm{mg} \mathrm{L}-1$. The highest growth with $0.08 \pm$ $0.006 \mathrm{~g} \mathrm{DW} /$ culture was obtained in the medium containing $2.0 \mathrm{mg} \mathrm{L}-1$ of 2,4-D after one month of culture. A decrease of dry weight to $0.07 \pm 0.00 \mathrm{~g}$ $\mathrm{DW} /$ culture was observed in the medium containing 2.5 $m g \mathrm{~L}^{-1}$ 2,4-D.

A further study was also done using $2.0 \mathrm{mg} \mathrm{L}^{-1}$ of 2,4-D in combination with kinetin, BAP or TDZ at the concentrations of $0.5,1.0$ and $1.5 \mathrm{mg} \mathrm{L}-1$. Since there was no callus induced from the MS basal medium without hormones (control), there was no dry weight value in this experiment. The result showed that the combination with $1 \mathrm{mg} \mathrm{L}^{-1}$ kinetin produced the highest callus yields $(0.27 \pm 0.01 \mathrm{~g} \mathrm{DW} /$ culture $)$ with friable white yellowish in colour, even higher than that in 2.0 $\mathrm{mg} \mathrm{L}^{-1}$ of 2,4-D (Table 1C). In addition, the combination with BAP also managed to maintain the proliferation of callus although at a lower rate compared to kinetin. The callus yield was increased around $34.4 \%$ with $0.5 \mathrm{mg} \mathrm{L}^{-1}$ to $1.5 \mathrm{mg} \mathrm{L}^{-1} \mathrm{BAP}$ supplementation. Low proliferating greenish callus was observed in medium supplemented with TDZ in combination with $2 \mathrm{mg} \mathrm{L}^{-1} 2,4-\mathrm{D}$ as compared to the other cytokinins combination. The data obtained also showed that the callus yield was decreased significantly around $45.8 \%$ when the concentrations of TDZ increased.

Through this study, we found that the combination of $2 \mathrm{mg} \mathrm{L}^{-1} 2,4-\mathrm{D}$ with $1 \mathrm{mg} \mathrm{L}^{-1}$ kinetin gave the highest proliferation rate. Thus, different types of $C$. asiatica calli were induced and maintained in the MS basal medium supplemented with $2.0 \mathrm{mg} \mathrm{L}^{-1} 2,4-\mathrm{D}$ and $1.0 \mathrm{mg} \mathrm{L} \mathrm{L}^{-1}$ kinetin. They produced four different colours which were brownish yellow, yellow, red and green (Fig. 1).

Callus growth curve: This study aimed to determine the most suitable growth time point for callus harvesting with the highest flavonoid content. The 
growth of callus was determined based on the fresh and dry weights of the cultures. The pattern of the growth curve was obtained and showed an initial lag phase followed by a period of rapid growth (exponential), as illustrated in Fig. 2A.

Upon transferring the calli to the maintenance medium, very little increase of biomass was observed in the calli during the first four days of culture (the lag phase). After six days of culture, the calli were found in their exponential phase as the cells were rapidly divided and proliferated. During the lag phase of the culture, the flavonoid content was steady at around $2.2 \mathrm{mg} \mathrm{g}^{-1} \mathrm{DW}$. When the culture entered the early exponential phase, the flavonoid content started to increase (Fig. 2B). The highest yield of flavonoid was obtained on day 12 $\left(5.26 \pm 0.09 \mathrm{mg} \mathrm{g}^{-1} \mathrm{DW}\right)$. After 14 days of culture, the flavonoid content reduced until the culture reached the stationary phase. Based on the results obtained, 12 days old calli in the exponential phase were chosen for the subsequent experiments because the cells at this age are healthy, rapidly dividing and produce high flavonoid content.

Cell line selection: The fastest growing leaf-derived calli among the four accessions were identified after 12 days. Evidently, UPM03 achieved the highest fresh weight (i.e., $0.67 \pm 0.02 \mathrm{~g} /$ culture) and dry weight (i.e., $0.041 \pm 0.004 \mathrm{~g} /$ culture) within this period. This was followed by UPM04, i.e., $0.67 \pm 0.03 \mathrm{~g} \mathrm{FW/culture,}$ UPM02, i.e., $0.59 \pm 0.02 \mathrm{~g} \mathrm{FW/culture} \mathrm{and} \mathrm{UPM01,}$ i.e., $0.54 \pm 0.02 \mathrm{~g} \mathrm{FW/culture.} \mathrm{The} \mathrm{result} \mathrm{of} \mathrm{dry}$ weight demonstrated a similar pattern as shown in fresh weight (Fig. 3A).

The calli of the four accessions were also analysed for their flavonoid content using spectrophotometry (Fig. 3B), while individual flavonoids were identified by HPLC (Fig. 4). The data obtained revealed that the highest unhydrolysed flavonoid content, i.e., $5.77 \pm$ $0.04 \mathrm{mg} \mathrm{g}^{-1}$ DW was observed in the calli of UPM02. In contrast, UPM03, with $4.03 \pm 0.07 \mathrm{mg} \mathrm{g}^{-1} \mathrm{DW}$, was found to be the lowest in unhydrolysed flavonoid content. For the unhydrolysed flavonoid content, the results varied about $30 \%$ among them. Similarly, for hydrolysed flavonoid content, significant different's were found between the four group (Fig. 3B). Callus UPM03 showed the highest cell growth rate and most effective flavonoid formation with $10.75 \pm 0.30 \mathrm{mg} \mathrm{g}^{-1}$ DW (Fig. 3B). In the HPLC analysis, the four flavonoid compounds, viz., luteolin, quercetin, apigenin and kaempherol were detected among the four accessions. Fig. 4 shows that quercetin and luteolin were the major flavonoid compounds among them. Both quercetin and luteolin, which have been detected in UPM03, had the highest amounts (i.e., $0.146 \pm 0.003 \mathrm{mg} \mathrm{g}^{-1}$ DW and

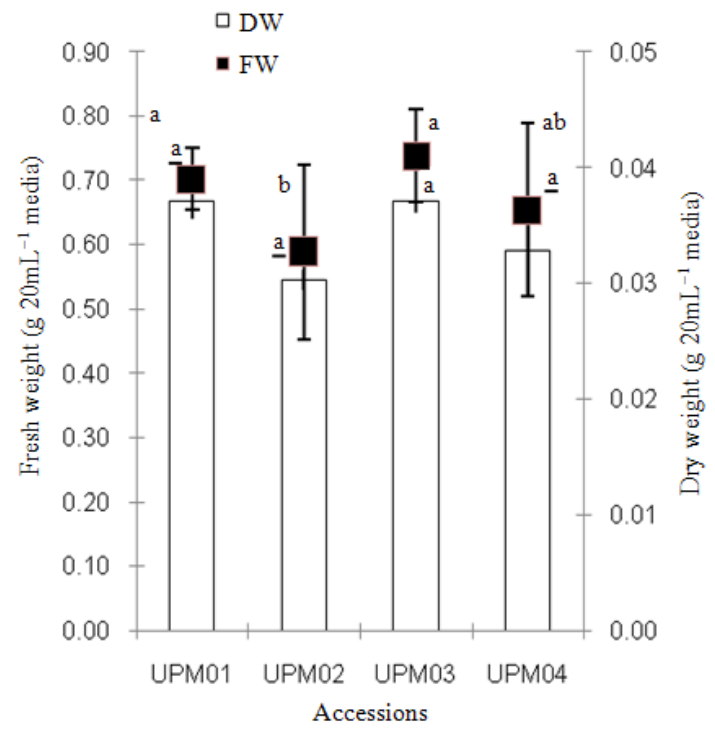

(a)

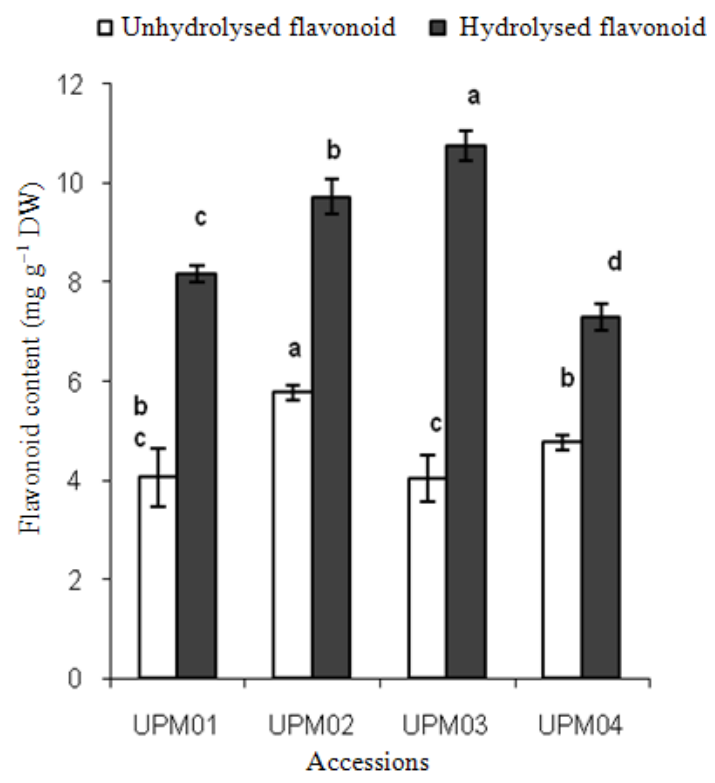

(b)

Fig. 3: The biomass growth (A) and the unhydrolysed and hydrolysed flavonoid contents (B) of different accessions of C. asiatica. Twelve-days old leaf-derived calli cultured on the MS basal medium supplemented with 2,4-D: kinetin (2:1 $\mathrm{mg} \mathrm{L} \mathrm{L}^{-1}$ ) incubated at $25^{\circ} \mathrm{C}$ under $16 \mathrm{~h}$ photoperiod. The calli was harvested after twelve-days of inoculation. The bar indicates the standard deviation of mean $(n=3)$. The different letters indicate that the values are significantly different $(\mathrm{P} \leq 0.05)$. The data for dry weight are indicated using underlined letters 
Am. J. Biochem. \& Biotech., 6 (4): 284-299, 2010

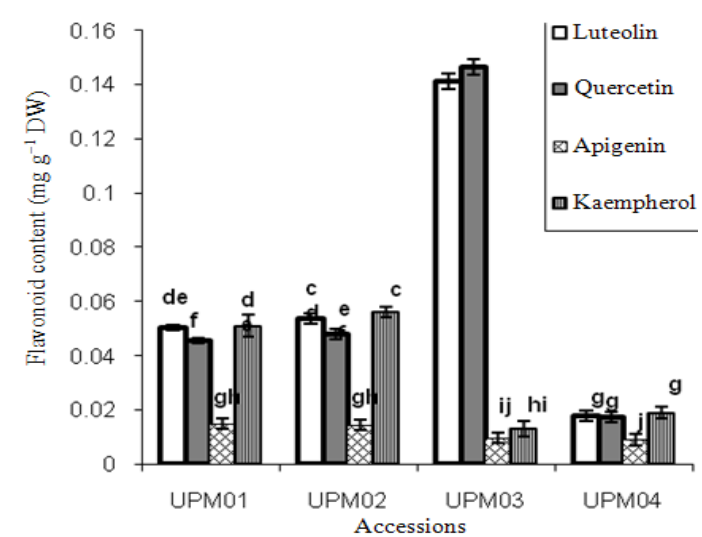

Fig. 4: The content of individual flavonoid detected in different accessions of C. asiatica from HPLC method. The bar indicates the standard deviation of mean $(\mathrm{n}=3)$. The different letters indicate that the values are significantly different $(\mathrm{P} \leq 0.05)$

$0.141 \pm 0.003 \mathrm{mg} \mathrm{g}^{-1} \mathrm{DW}$, respectively) as compared to the other accessions. Meanwhile, UPM02 produced the highest amount of kaempherol with $0.056 \pm 0.002 \mathrm{mg}$ $\mathrm{g}^{-1}$ DW.

Establishment of cell suspension: Six hormones were used in the establishment of cell suspension cultures of UPM03 (which were; 3 auxins viz. Picloram, 2,4-D, NAA, 3 cytokinins viz. TDZ, kinetin and BAP). The performances of each hormone in various concentrations are shown in Fig. 5. White and homogenous small cell aggregates were obtained at the beginning of the cell suspension cultures on the MS basal medium supplemented with various concentrations of auxins. Among the three auxins, 2,4$\mathrm{D}$ gave the highest cell fresh and dry weights. The medium supplemented with $2.0 \mathrm{mg} \mathrm{L}^{-1} 2,4-\mathrm{D}$ was the best in cell weight followed by the supplementation with $1.0 \mathrm{mg} \mathrm{L}^{-1} 2,4-\mathrm{D}$. Cell growth increased as the concentration of NAA increased and a similar pattern was also observed for Picloram.

All the auxins, in different concentrations, enhanced the flavonoid production compared to the control treatment except with $1 \mathrm{mg} \mathrm{L}^{-1}$ Picloram and 2 mg L L NAA (Fig. 5C). By using $2 \mathrm{mg} \mathrm{L}^{-1} 2,4-\mathrm{D}$, a maximum flavonoid yield with $8.48 \mathrm{mg} \mathrm{g}^{-1}$ DW was observed. In the cells treated with Picloram, only those with higher concentrations were found capable of increasing the flavonoid production. However, these responses were markedly suppressed when the medium was supplemented with more than $2 \mathrm{mg} \mathrm{L}^{-1} 2,4-\mathrm{D}$ and Picloram. Nevertheless, in all the concentrations of NAA, there was no significant difference in the flavonoid production compared to the control.

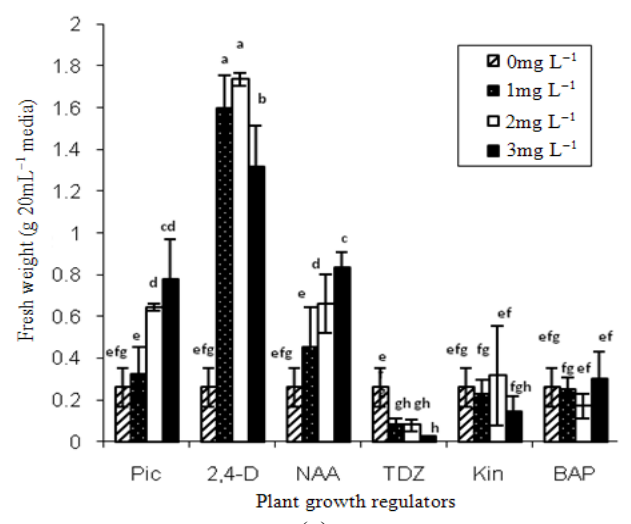

(a)

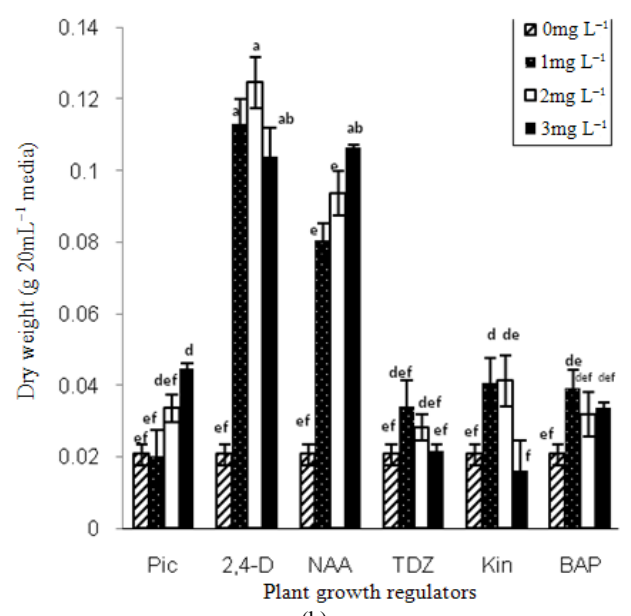

(b)

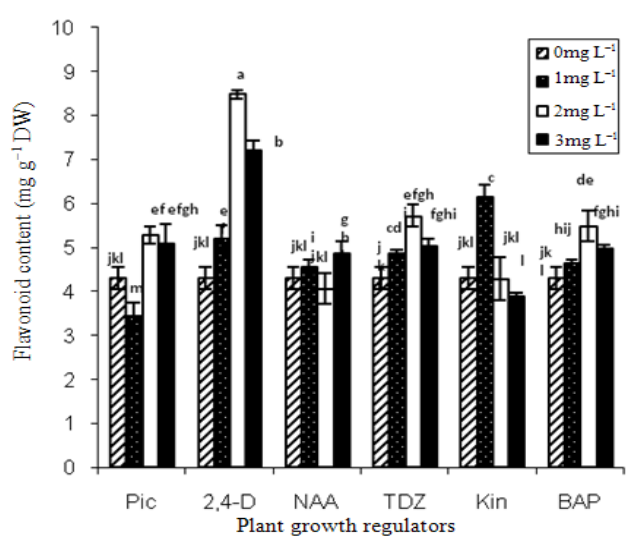

(c)

Fig. 5: The effect of different plant growth regulators on the fresh weight (A), dry weight (B) and flavonoid content $(\mathrm{C})$ of $\mathrm{C}$. asiatica accession of UPM03 cell suspension culture. The bar indicates the standard deviation of mean $(\mathrm{n}=3)$. The different letters indicate that the values are significantly different $(\mathrm{p} \leq 0.05)$ 
All of the cells treated with different concentrations of cytokinins have been sieved using a pore size of 750 $\mu \mathrm{m}$. The fresh and dry weights of the suspended cells were then determined. The study of the cytokinin effects revealed that none of them supported the disengagement of $C$. asiatica cells. Among the various cytokinins tested, kinetin, using concentrations between 1 to $2 \mathrm{mg} \mathrm{L}-1$, was found to be a better candidate for cell growth (disengagement) (Fig. 5). A significant decrease $(14.6 \%)$ of cell growth was also observed for the cells treated with $3 \mathrm{mg} \mathrm{L}^{-1}$ of kinetin. On the other hand, in TDZ treatment, the highest growth was achieved in $1 \mathrm{mg} \mathrm{L}^{-1}$ treated cells. A tendency for growth decrease was noticed in the cells treated with concentrations higher than $1 \mathrm{mg} \mathrm{L}-1$. Meanwhile, no significant differences in cell growth were observed in BAP treatment and the control cells.

Cytokinins were found to support the production of flavonoids in the range of $3.90-6.16 \mathrm{mg} \mathrm{g}^{-1} \mathrm{DW}$ (Fig. 5). A maximum flavonoid production of $6.16 \mathrm{mg}$ $\mathrm{g}^{-1} \quad$ DW was obtained at $1 \mathrm{mg} \quad \mathrm{L}^{-1}$ kinetin supplementation. A tendency in reduced production of flavonoids was identified in kinetin when increasing its concentration. The concentration of $2 \mathrm{mg} \mathrm{L}^{-1} \mathrm{TDZ}$ and BAP could produce higher flavonoid concentrations compared to other concentrations tested.

When comparing the moisture contents between the auxin treated cells, a higher percentage was observed in the 2, 4-D treated cells. In this treatment, the suspension cells stored around $93 \%$ of water in the vacuole. The moisture content of the cell decreased sequentially with the increase in Picloram concentration. In comparison, the moisture content increased gradually from $82-87 \%$ with increasing concentration of NAA. A moisture content of about $92 \%$ was observed in the control cells. The moisture content increased from $82 \%$ to $88 \%$ as the concentration of the kinetin increased. A similar pattern was also observed for BAP treatment. On the contrary, it was revealed that $2 \mathrm{mg} \mathrm{L}^{-1}$ of TDZ did not support the cell survival rate. In fact, only a 5\% moisture content was observed in the cells treated with $3 \mathrm{mg} \mathrm{L}^{-1}$ TDZ, which showed the lowest fresh and dry weights among the treatments.

Cell suspension growth curve: The growth kinetics for the cell suspension culture of UPM03 treated with the combination of $2.0 \mathrm{mg} \mathrm{L}^{-1} 2,4-\mathrm{D}$ and $1 \mathrm{mg} \mathrm{L}^{-1}$ kinetin were determined. As illustrated in Fig. 6A, no lag phase was observed for both fresh and dry weights.

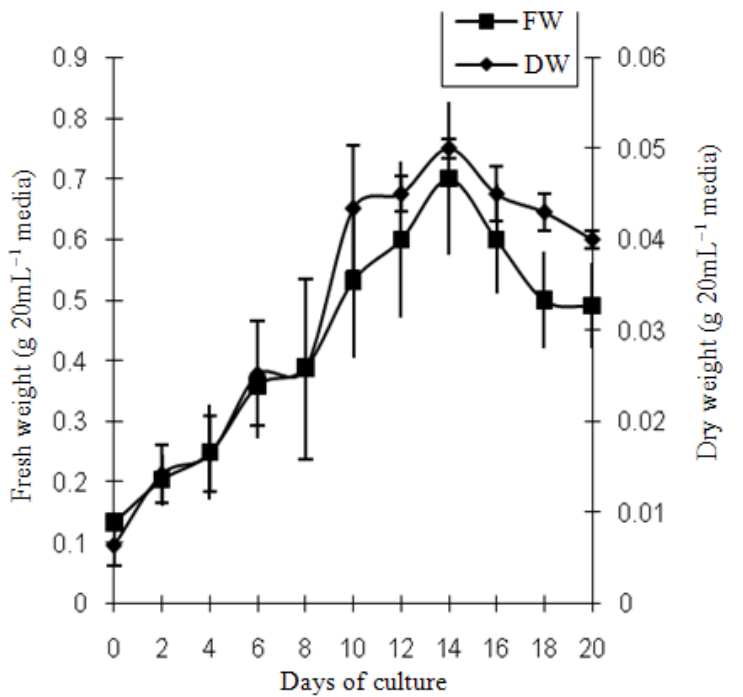

(a)

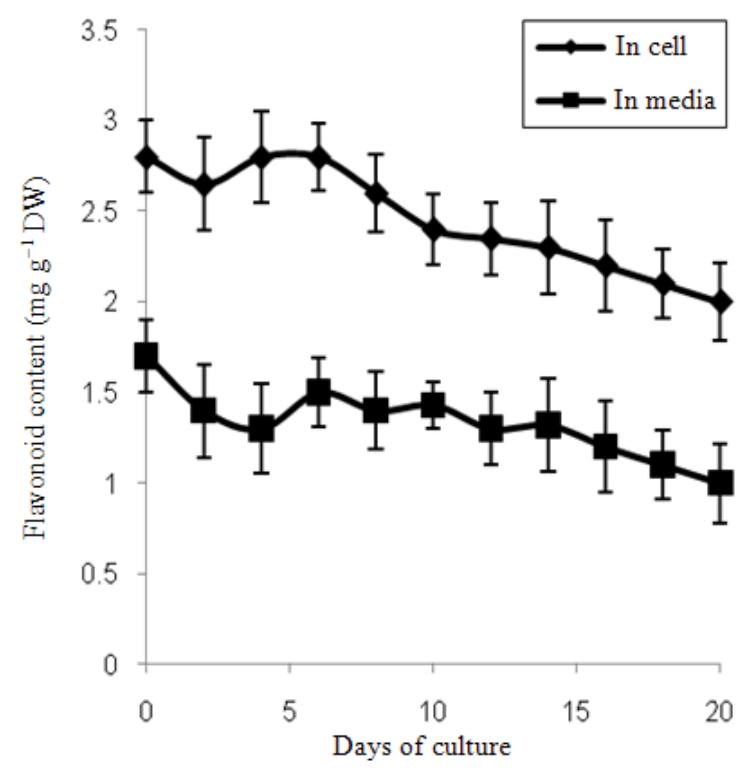

(b)

Fig. 6: Time course for the growth of cell suspension (A) and flavonoid content (B) of C. asiatica accession of UPM03. $0.1 \mathrm{~g}$ of wet cells in 20 $\mathrm{ml}$ of MS medium in B5 vitamin supplemented with 2,4-D: kinetin $(2: 1 \mathrm{mg} / \mathrm{L})$ was used as the initial inoculum size. The bar indicates the standard deviation of mean $(n=3)$

However, flavonoids were not significantly produced in cells or released into the culture medium

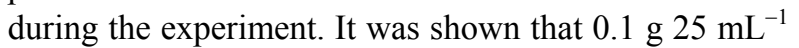
inoculum was sufficient in supporting cell growth, but 
could not support the production of flavonoids either in the cells or in the media (Fig. 6B)

\section{DISCUSSION}

Juvenile explants for the initiation of in vitro cultures are primarily favoured because of their high morphogenetic potential and low level of contamination (Yang et al., 2009). On the contrary, establishing in vitro cultures of plant using mature tissues as explants could not be always accomplished, mainly due to the high contamination rates, reduction or absence of morphogenetic ability and poor rooting of regenerated shoots. Hence, the fully expanded young leaves were chosen instead for the subsequent experiments. Auxins play an important role in callus induction, whereby different types of auxins can give various effects (Baskaran et al., 2006). Naturally occurring auxins are known as IAA and IBA. There are also auxins synthesized from chemical analogues, namely: NAA, 2,4-D, Dicamba and Picloram. These synthetic auxins are in many cases more effective than the natural auxins as reviewed in Baskaran et al. (2006). Observation of the callus as friable and whitish green using 2,4-D has been also reported by Gopi and Vatsala (2006). In their observation, the calli induced from the young leaves of Gymnema sylvestre R.Br, in 2,4-D supplemented medium, were loosely well developed and albino colour. This finding is also supported by Zhao et al. (2010) and Tohidi-Moghadam et al (2009). Whereas for NAA, low callusing index was also reported by Cenkci et al. (2008). This finding was contradicted, who reported that the hypocotyls explant of Lycopersicon esculentum cultured on MS medium supplemented with $0.5 \mathrm{mg} \mathrm{L}^{-1}$ NAA gave the highest callusing index. Mohapatra et al. (2008) and. (Banerjee et al., 1999) also found the formation of adventitious roots during the callus induction using IBA. On the other hand, 2, 4$\mathrm{D}$ was superior to other auxins in the callus induction of C. asiatica. This was because 2,4-D, a synthetic auxin, increases callus induction at a higher rate compared to other types of auxin. NAA and IBA were weaker in callus initiation because they were more prone to induce root formation. This finding was in agreement with Lee et al. (2007), who showed that 2,4-D was better and exhibited 50\% higher induction rate, compared to NAA in orchardgrass (Dactylis golomerata L.). Martin (2004) also found maximum callus formation (1380 $\mathrm{mg} \mathrm{FW}$ ) in C. asiatica by using $2.0 \mathrm{mg} \mathrm{L}^{-1} 2,4-\mathrm{D}$ alone as compared with other auxins, such as $2.0 \mathrm{mg} \mathrm{L}^{-1} \mathrm{NAA}$ and $2.0 \mathrm{mg} \mathrm{L}^{-1}$ IAA with 1305 $\mathrm{mg} \mathrm{FW}$ and $1240 \mathrm{mg} \mathrm{FW}$, respectively. In addition, friable, rapidly growing whitish green callus was produced by leaf explants cultured with $2.0 \mathrm{mg} \mathrm{L}^{-1} 2,4-$ D. Salma et al. (2008) reported that the frequency of callusing increased from 54.12 to $96.43 \%$ with the increasing concentrations of auxin from 0.2 to $2.0 \mathrm{mg} \mathrm{L}^{-}$ ${ }^{1}$. However, in this study, when the auxin concentration surpassed $2.0 \mathrm{mg} \mathrm{L}^{-1}$, decreased level of callus induction was observed due to a high concentration of 2,4-D which caused toxicity to the explants and/or calli after four weeks in culture (Hutchinson et al., 1994). The explants supplied with 1.0-2.5 $\mathrm{mg} \mathrm{L}^{-1}$ of 2,4-D, gave very similar results with explants forming callus $>80 \%$. From an economic point of view, one should choose $1 \mathrm{mg} \mathrm{L}^{-1} 2,4-$ D which gave $83.3 \%$ formation callus compared with that of $2 \mathrm{mg} \mathrm{L}^{-1} 2,4-\mathrm{D}$ which gave $86.6 \%$. However, for experimental purposes, $2 \mathrm{mg} \mathrm{L}^{-1} 2,4-\mathrm{D}$ was used for subsequent experiments since it gave the highest callus formation rate.

Some explants needed to be cultured in dark conditions in order to increase the callus efficiency and reduce the secretion of phenolic compounds, which generally affected the explants survival. $\mathrm{Xu}$ et al. (2009) reported an efficient tissue culture protocol in their study on Juncus effusus L., which produced $90.48 \%$ callus formation in the MS medium containing $4 \mathrm{mg} \mathrm{L}^{-1}$ 2,4-D and $0.5 \mathrm{mg} \mathrm{L}^{-1}$ BAP. However, this study was conducted under light conditions and resulted in efficient callogenesis. Besides that, an advantage of light conditions was the induction of some of the secondary metabolites (Bakhshi and Arakawa, 2006; Abreu et al., 2005). Nath and Buragohain (2005) reported that the leaf explants of India C. asiatica cultured in the MS basal medium supplemented with $1.0 \mathrm{mg} \mathrm{L}^{-1} 2,4-\mathrm{D}$ and $0.5 \mathrm{mg} \mathrm{L}^{-1}$ as well as $1.5 \mathrm{mg} \mathrm{L}^{-1}$ 2,4-D and $1.5 \mathrm{mg} \mathrm{L}^{-1}$ BAP successfully induced yellowish callus on the 28th day. Notably, there was a significant reduction rate in callus induction response when auxin was applied together with cytokinin. This was because auxin acts by stimulating cell elongation and cell division in callus initiation as well as callus formation whereas cytokinin cause cell division that lead to shoot regeneration (Gaba, 2005). The effect of auxin in stimulating callus initiation has been suppressed by the high level of cytokinin that has the opposite effect from auxin. The suitable plant growth regulators for callus induction vary among species. For instance, the induction of calli from the anther segments of Dianthus chinensis L. was found to be optimized on the MS basal medium containing $1 \mathrm{mg} \mathrm{L}^{-1} 2,4-\mathrm{D}$ and $0.1 \mathrm{mg} \mathrm{L}^{-1}$ NAA. Similarly, the same result was also apparent in D. barbatus L. observed on the MS or B5 medium supplied with $1 \mathrm{mg} \mathrm{L}^{-1} \mathrm{TDZ}$ and $0.1 \mathrm{mg} \mathrm{L}^{-1}$ NAA (Nontaswatsri et al., 2008).

In most batches of cell cultures, flavonoid accumulation tends to increase at the end of the rapid 
cell division in the growth cycle. However, in some cases, the production of secondary products did not show a positive correlation with the maximal growth rate of the culture (Jacinda et al., 2008). Various reports have indicated that maximum production of flavonoid's achieved during the active growing stage of the cells (Zhao et al., 2001; Antonigni et al., 2007; Fu et al., 2005). Thus, we studied the effect of PGRs to increase the yield of callus biomass before proceeding to flavonoid production studies in order to prepare enough cells to produce the flavonoids wanted. Irrespective of the explants, 2,4-D was recommended to be the most widely used growth regulator for wheat callus induction and maintenance (Pellegrineschi et al., 2004). Yan et al. (2009) reported that the best callus proliferation rate was observed on B5 medium supplemented with $1.5 \mathrm{mg}$ $\mathrm{L}^{-1} 2,4-\mathrm{D}$ in the basal plate explants of Chinese jiaotou (Allium chinense). Our study revealed that a low concentration was inadequate for the optimal callus proliferation, whilst the concentration at $2.5 \mathrm{mg} \mathrm{L}^{-1}$ showed an inhibitory effect on the callus proliferation compared to $2.0 \mathrm{mg} \mathrm{L}^{-1} 2,4-\mathrm{D}$. It was indicated that at low concentrations, 2,4-D has an auxin-like property but it was herbicidal at higher concentrations. These findings were in accordance with those determined in the callus proliferation of Euphorbia helioscopia, whereby $1.0 \mathrm{mg} \mathrm{L}^{-1}$ of 2,4-D did not produce optimal callus yields, while exposure to $4 \mathrm{mg} \mathrm{L}^{-1} 2,4-\mathrm{D}$ led to $22 \%$ reduction in callus yield (Yang et al., 2009).

The previous research suggested that the combination of auxin and cytokinin always gave good callus proliferation and maintenance (Karami, 2008; Salma et al., 2008). Remarkably enhanced callus proliferation by the combination of cytokinin and auxin was also observed in Yi Mu Cao (Leonurus heteophylus Sw.) as reported by Yang et al. (2008). Cytokinins were found to not only stimulate cell division through regulation of specific genes, but to also act as membrane stabilizers and anti-ageing substance by reducing free radicals concentration that could destroy the membrane integrity. It seems likely that the promotive effect of kinetin in this study was due to its relatively lower biological activity, c.f. BAP, which provided an optimum balance of auxin and cytokinin for the induction and sustained growth of callus cultures (Siamak et al., 2010; Hutchinson et al., 1994). It showed that higher concentrations of BAP gave better callus proliferation rates. Furthermore, a study by Jacinda et al. (2008) revealed that they maintained the C. asiatica callus in the MS medium supplemented with $0.22 \mathrm{mg} \mathrm{L}^{-1} 2,4-\mathrm{D}$ and $0.23 \mathrm{mg} \mathrm{L}^{-1} \mathrm{BAP}$ and managed to produce triterpenoids. It was found that
TDZ generally tended to promote the formation of compact-green nodular callus (Murthy et al., 1998). TDZ might stimulate de novo synthesis of auxins, as high level of auxins would lead to stunting and eventually necrosis of the cell (Siamak et al., 2010; Murthy et al., 1998). This finding contradicted AlJuboory et al. (1998) who suggested that the combination of TDZ (2.20 mg L-1) and IAA $(0.44 \mathrm{mg}$ L-1) was more effective for callus production from gardenia. This is because TDZ is more potent to promote callus from shrub plant.

In callus maintenance, we found that red colour could have resulted from the presence of anthocyanin while the green colour might be due to the chlorophyll content in the calli. It was also observed that the red calli proliferated faster than the normal calli.

Flavonoids were produced during the exponential phase of the callus growth (Antonigni et al., 2007; Fu et al., 2005; Andreazza et al., 2008 while most of the secondary metabolites were produced when the cultures entered the stationary or death phase (Abbasi et al., 2007; Miguel-Chavez et al., 2003 Arias-Castro et al., 1993). Likewise, a similar finding was also observed in the compact callus aggregate of Rhodiola sachalenensis, where high salidroside was produced when it entered the log phase of the cultures ( $\mathrm{Wu}$ et al., 2003). Conversely, in Eschscholtzia californica suspension cultures, dihydrosanguinarine accumulated to a maximal level of $338.0 \pm 20.3 \mathrm{mg} \mathrm{L}^{-1}$ after only five days of culture (Cho et al., 2008). Variation in the biomass growth among the four accessions was expected because the callus growth capacity was significantly different among different cell lines as reported in Orthosiphon Stamineus Benth (Lim et al., 2006). As observed in Fig. 4, even in the same species but with different accessions, the flavonoid content may differ in type or concentration. Likewise, this finding was consistent with the study carried out by Jacinda et al. (2008), who found a difference in concentration of bioactive triterpenoids between the two phenotypes of $C$. asiatica. Lim et al. (2006) also reported that all eight cell lines of Orthosiphon stamineus Benth. exhibited the same growth pattern but produced different maximum cell biomasses as well as different amounts of rosmarinic acid in the cell suspension cultures. Our results suggested that cell line selection is a crucial step in ensuring consistent high-quality bioactive compounds from $C$. asiatica callus cultures.

Our finding in cell suspension establishment was consistent with previous findings for callus proliferation rates using different auxins in $1 \mathrm{mg} \mathrm{L}{ }^{-1} 2,4-\mathrm{D}$ (Table 1). 
2,4-D was the best auxin in supporting the growth of callus, followed by picloram and then NAA. NAA seem to be have more effect in supporting the growth of cell suspension rather than callus growth. Generally, high auxin levels are often deleterious to secondary metabolite production (Wu et al., 2006). It is interesting to note the effect of 2,4-D in enhancing flavonoid as this is often found to support good growth but inhibits the secondary metabolite formation (Whitmer et al., 1998; Arvy et al., 1994). However, this outcome was consistent with the previous finding. They revealed that the biomass growth, as well as the berberine formation, were increased by increasing the 2,4-D concentration. In contrast, in the compact callus aggregate of Rhodiola sachalenensis, the addition of 2,4-D was found to inhibit cellular growth and stimulate salidroside accumulation by day 9 of the cultures (Wu et al., 2003). Although cytokinins function to promote cell division, it was found that most of the cells did not detach from each other and formed bigger clumps after culturing for 10 days and were retained in the sieve. As a result, the fresh weight and dry weight readings were relatively lower with the application of cytokinins as compared to auxins. This might be due to an increase in the cell division rate until most of the cells were too big and could not go through the filter pores and were retained on the sieve (which were not counted as fresh weight or dry weight). This suggested that the cells tended to become bigger clumps rather than disengage or form single cells with the application of cytokinins. Maurmann et al. (2006) observed that the addition of kinetin in the medium showed few effects on the growth of the cultures (Valeriana glechomifolia) but promoted valepotriate formation in the cultures with a low degree of differentiation.

The differences between the fresh weight and dry weight of the suspension cells mainly reflects the moisture content of the tissues. The fresh weigh to dry weight ratio is a useful indicator for cell viability. This is because, the higher the ratio, the higher the cell viability is (Fu et al., 2005). Higher concentrations of Picloram caused damage to the cells whereas NAA only has a slight effect in damaging the cells (Mishiba et al., 2001). TDZ was unlikely to support the survival of cell suspensions of $C$. asiatica as they exhibited a characteristic stunted growth pattern (Murthy et al., 1998). Generally, the cells treated with cytokinins had lower moisture content as compared to the cells treated with auxins. This indicated that using cytokinins alone in establishing the cells was not enough to sustain the tissues.
In cell suspension growth curves, cells required only a short period of time for adaptation after being sub-cultured. It was also shown that $0.1 \mathrm{~g}$ of wet cells (5 mL) cultured into a $20 \mathrm{~mL}$ of liquid medium was adequate to support the growth of the suspension cultures. The maximum biomass (fresh and dry weights) was achieved on day 14, after which a reduction of total biomass was observed.

The C. asiatica cells initiated in this study were found to have faster growth in comparison to the $C$. asiatica cells established by Nath and Buragohain (2005). In addition, the cell suspension culture of $C$. asiatica accession UPM03 attained maximum biomass growth in a shorter time compared to its callus culture. The result was consistent with the $C$. asiatica cell suspension reported by Nath and Buragohain (2005) which demonstrated a lag phase of up to ten days of incubation followed by a steep rise in the growth rate until the third week whereupon the callus culture took until the eighth week to reach stationary phase. This may be because the cell suspension cultures had homogenous cell clumps and had better contact with the supplied liquid medium whereas only the bottom surface of callus cultures were in contact with the solid medium. Our result was consistent with the insignificant production of saponin by using Panax ginseng suspension cultures when using a low inoculum size (1.5 g DW/L) (Akalezi et al., 1999).

\section{CONCLUSION}

In conclusion, the friable, green calli were successfully maintained on MS basal medium with 2 $\mathrm{mg} \mathrm{L} \mathrm{L}^{-1}$ 2,4-D and $1 \mathrm{mg} \mathrm{L}^{-1}$ kinetin. The studies revealed that medium supplemented with combination of hormones managed to induce and establish calli. However, 2,4-D alone at $2 \mathrm{mg} \mathrm{L}^{-1}$ had the high percentage of calli. It was found that flavonoid was being produced during the exponential phase of the callus culture. Among the leaf-derived calli of the four accessions, the calli of UPM03 showed the highest values in biomass yield and total flavonoid content. Maximum total flavonoid content was achieved during the exponential phase (day 12). A successful flavonoid enhancement has been achieved, especially for luteolin and quercetin, in the callus system of UPM03 which was about 100-fold and 11-fold higher than the onemonth-old leaf tissues from the intact plant of UPM03, respectively. This study provides basic information for the massive production of flavonoid in C. asiatica. By indentifying the elite accession of Malaysian C. asiatica callus, further studies using this plant material in cell suspension cultures on different aspect can be 
manipulated to increase biosynthesis of flavonoids especially luteolin for commercial production.

Among the auxins and cytokinins tested, the MS basal medium supplemented with $2 \mathrm{mg} \mathrm{L}^{-1}$ 2,4-D gave the highest fresh and dry weights in the cell suspension cultures of $C$. asiatica. In addition, the flavonoid content was found higher in $2 \mathrm{mg} \mathrm{L}^{-1} 2$,-D and $1 \mathrm{mg}$ $\mathrm{L}^{-1}$ kinetin as compared among their own group. The kinetic growth curve was developed using $0.1 \mathrm{~g}$ of wet cells (as the initial inoculum size) and cultured in 25 $\mathrm{mL}$ MS medium in B5 vitamin supplemented with 2,4D: kinetin $(2: 1)$ at $25 \pm 2{ }^{\circ} \mathrm{C}$ using a regime of $16 \mathrm{~h}$ of light and $8 \mathrm{~h}$ of darkness and showed a sigmoid curve. However, there was no significant difference in flavonoid production either in the cells or in the media within the cultivation period. Hence, to overcome the lack of flavonoid production, both in the cells and in the media, further studies on the aggregation of the cells and the culture conditions will be carried out.

\section{ACKNOWLEDGEMENT}

The researchers would like to thank Universiti Putra Malaysia for its Graduate Research Fellowship (GRF).

\section{REFERENCES}

Abbasi, B.H., C.L. Tian, S.J. Murch, P.K. Saxena and C.Z. Liu, 2007. Light-enhanced caffeic acid derivatives biosynthesis in hairy root cultures of echinacea purpurea. Plant Cell Rep., 26: 1367-1372. DOI: $10.1007 / \mathrm{s} 00299-007-0344-5$

Abreu, I.N.D., A.C.H.F. Sawaya, M.N. Eberlin and P. Mazzafera, 2005. Production of pilocarpine in callus of jaborandi (pilocarpus microphyllus stapf). Vitro Cellular Dev. Biology-Plant, 41: 806-811. DOI: 10.1079/IVP2005711

Akalezi, C.O., S. Liu, Q.S. Li, J.T. Yu and J.J. Zhong, 1999. Combined effects of initial sucrose concentration and inoculum size on cell growth and ginseng saponin production by suspension cultures of panax ginseng. Process Biochem., 34 639-642. DOI: 10.1016/S0032-9592(98)00132-0

Al-Juboory, K.H., R.M. Skirvin and D.J. William, 1998. Callus induction and adventitious shoot regeneration of gardenia (gardenia jasminoisides ellis) leaf explants. Sci. Hortic., 72: 171-178. DOI: 10.1016/S0304-4238(97)00060-5

Andreazza, N.L., I.N. Abreu, A.C.H.F. Sawaya, M.N. Eberlin and P. Mazzafera, 2008. Production of imidazole alkaloids in cell cultures of jaborandi as affected by the medium ph. Biotechnol. Lett. 31: 607-614. DOI: 10.1007/s10529-008-9895-y
Antonigni, F., S. Zheng, C. Pagnucco, R. Baraldi and F. Poli et al., 2007. Induction of flavonoid production by UV-B radiation in Passiflora quagrangularis passiflora callus cultures. fitoterapia 78: 345-352. DOI: 10.1016/j.fitote.2007.02.001

Arias-Castro, C., A.H. Scragg and M.A. Rodriguez-Mendiola, 1993. The effect of cultural conditions on the accumulation of formononetin by suspension cultures of glycyrrhiza glabra. Plant Cell. Tiss. Org., 34: 63-70. DOI: 10.1007/BF00048464

Arvy, M.P., N. Imbault, F. Naudascher, M. Thiersault and P. Doireau, 1994. 2, 4-D and alkaloid accumulation in periwinkle cell suspensions. Biochemistry, 76: 410-416. DOI: 10.1016/03009084(94)90117-1

Bakhshi, D. and O. Arakawa, 2006. Induction of phenolic compounds biosynthesis with light irradiation in the flesh of red and yellow apples. J. Appl. Hortic., 8: 101-104. http://www.horticultureresearch.net/Induction $\% 20$ of $\% 20$ phenolic $\% 20$ compounds $\% 20$ biosynthesis $\% 2$ 0with\%20light $\% 20$ irradiation\%20\%2017-20.pdf

Banerjee, S., M. Zehra and S. Kumar, 1999. In vitro multiplication of centella asiatica, a medicinal herb from leaf explants. Curr. Sci. India 76: 147-148. http://www.bioone.org/doi/abs/10.1007/s11627007-9040-y

Baskaran, P., B.R. Rajeswari and N. Jayabalan, 2006. Development of an in vitro regeneration system in sorghum [Sorghum bicolor (L). Moench] using root transverse Thin Cell Layers (tTCLs). Turk. J. Bot., $\quad 30: \quad 1-9$. http://journals.tubitak.gov.tr/botany/issues/bot-0630-1/bot-30-1-1-0502-3.pdf

Brinkhaus, B., M. Lindner, D. Schuppanand E.G. Hahn, 2000. Chemical, pharmacological and clinical profile of the East Asian medical plant centella asiatica. Phytomedicine, 7: 427-448. PMID: 11081995

Cenkci, S., M. Kargioglu, S. Dayan and M. Konuk, 2008. In vitro propagation of an endangered plant species, thermopsis turcica (fabaceae). Biologia, 63: 652-657. DOI: 10.2478/s11756-008-0125-9

Chakraborty, A. and S. Chattopadhyay, 2008. Stimulation of menthol production in mentha piperita cell culture. Vitro Cellular Dev. BiologyPlant, 44: 518-524. DOI: 10.1007/s11627-0089145-y

Cheng, C.L. and M.W.L. Koo, 2000. Effects of centella asiatica on ethanol induced gastric mucosal lesions in rats. Life Sci., 67: 2647-2653. DOI: 10.1016/S0024-3205(00)00848-1 
Cho, H.Y., S.Y. Son, H.S. Rhee, S.Y.H. Yoon and C.W.T. Lee-Parsons et al., 2008. Synergistic effects of sequential treatment with methyl jasmonate, salicylic acid and yeast extract on benzophenanthridine alkaloid accumulation and protein expression in eschscholtzia californica suspension cultures. J. Biotechnol., 135: 117-122. DOI: $10.1016 /$ j.jbiotec.2008.02.020

Cook, N.C. and S. Samman, 1996. Flavonoidschemistry, metabolism, cardioprotective effecst and dietary sources. Nutr. Biochem., 7: 66-76. DOI: $10.1016 / \mathrm{S} 0955-2863(95) 00168-9$

Crozier, A., E. Jensen, M.E.J. Lean and M.S. McDonald, 1997. Quantitative analysis of flavonoids by reversed-phase high-performance liquid chromatography. J. Chromatogr. A., 761: 315-321. DOI: 10.1016/S0021-9673(96)00826-6

Fu, C.X., D.X. Zhao, Y. Huang and F.S. Ma, 2005. Cellular aggregate size as the critical factor for flavonoid production by suspension cultures of saussurea medusa. Biotechnol. Lett., 27: 91-95. DOI: 10.1007/s10529-004-6934-1

Gaba, V.P. 2005. Plant Growth Regulators in Plant Tissue Culture and Development. In: Plant Development and Biotechnology. Trigiano, R.N. and D.J. Gray (Eds.). CRC Press, Washington DC., pp: 87-99.

Gamborg, O.L., R.A. Miller and K. Ojima, 1968. Nutrient requirements of suspension cultures of soybean root cells. Exp. Cell. Res. 50: 151-158. DOI: 10.1016/0014-4827(68)90403-5

Gopi, C. and T.M. Vatsala, 2006. In vitro studies on effects of plant growth regulators on callus and suspension culture biomass yield from gymnema sylvestre. R. Br. Afr. J. Biotechnol., 2: 1215-1219. http://ajol.info/index.php/ajb/article/viewFile/6084 $7 / 49059$

Hasan, S.M.R., M. Jamila, M.M. Majumder, R. Akter, M.M. Hossain and M.E.H. Mazumder et al., 2009. Analgesic and antioxidant activity of the hydromethanolic extract of Mikania scandens (L.) willd leaves. Am. J. Pharmacol. Toxicol., 4: 1-7. DOI: 10.3844/ajptsp.2009.1.7

Hutchinson, M.J., J.M. Tsujita and P.K. Saxena, 1994. Callus induction and plant regeneration from mature zygotic embryos of a tetraploid alstroemeria (A. pelegrina $\mathrm{x}$ A. cinapsitta). Plant Cell Reports, 14: 184-187. DOI: 10.1007/BF00233787

Jacinda, J.T., R. Meyer and I.A. Dubery, 2008. Characterisation of two phenotypes of centella asiatica in Southern Africa through the composition of four triterpenoids in callus, cell suspensions and leaves. Plant Cell. Tiss. Org., 94: 91-99. DOI: $10.1007 / \mathrm{s} 11240-008-9391-\mathrm{z}$
Karami, O. 2008. Induction of embryogenic callus and plant regeneration in carnation (Dianthus caryophyllus L.). OnLine J. Bio. Sci., 8: 68-72. DOI: $10.3844 /$ ojbsci.2008.68.72

Lee, S.H., N. Ahsan, K.W. Lee, D.G. Lee and I. Alam et al., 2007. Re-evaluation of mature seed-derived callusing and regeneration potential of nine orchardgrass (dactylis golomerata L.) cultivars. Plant Tiss. Cult. Biotechnol., 17: 193-207. DOI: 10.3329/ptcb.v17i2.3240

Lentini, A., C. Forni, B. Provenzano and S. Beninati, 2007. Enhancement of transglutaminase activity and polyamine depletion in B16-F10 melanoma cells by flavonoids naringenin and hesperitin correlate to reduction of the in vivo metastatic potential. Amino. Acids., 32: 95-100. DOI: 10.1007/s00726-006-0304-3

Liang, L.F., C.L. Keng and B.P. Lim, 2006. Selection of cell lines for the production of rosmarinic acid from cell suspension cultures of Orthosiphon stamineus benth. Vitro Cellular Dev. Biology-Plant, 42: 538-542. DOI: 10.1079/IVP2006813

Marinova, D., F. Ribarova and M. Atanassova, 2005. Total phenolics and total flavonoids in bulgarian fruits and vegetables. J. Univ. Chem. Technol. Metall., 40: 255-260. http://www.uctm.edu/journal/j2005-

3/Marinova.pdf

Martin, K.P., 2004. Plant regeneration through somatic embryogenesis in medicinally important centella asiatica L. Vitro Cellular Dev. Biology-Plant, 40: 586-591. http://www.jstor.org/pss/4293798

Mato, L., J. Wattanathorn, S. Muchimapura, T. Tongun and N. Piyawatkul et al., 2009. Centella asiatica Improves Physical Performance and HealthRelated Quality of Life in Healthy Elderly Volunteer. Evidence-Based Complete Alternation Medicine, PMID: 19880441

Maurmann, N., C.M.B.D. Carvalho, A.L. Silva, A.G. Fett-neto and G.L.V. Poser et al., 2006. Valepotriates accumulation in callus, suspended cells and untransformed root cultures of valeriana glechomifolia. Vitro Cellular Dev. Biology-Plant, 42: 50-53. DOI: 10.1079/IVP2005725

Miguel-Chavez, R.S., M. Soto-Hernandez, A.C. RomosValdivia, G. Kite and M. Martinez-Vazquez et al., 2003. Production of alkaloids by in vitro culture of erythrina americana miller. Biotechnol. Lett., 25: 1055-1059. DOI: 10.1023/A:1024142531691

Mishiba, K.I., T. Okamoto and M. Mii, 2001. Increasing ploidy level in cell suspension cultures of doritaenopsis by exogenous application of 2,4dichlorophenoxyacetic acid. Physiol. Plantarum., 112: $\quad 142-148 . \quad$ DOI: $\quad 10.1034 / \mathrm{j} .1399-$ 3054.2001.1120119.x 
Mohandas, R.K.G., R.S. Muddanna and R.S. Gurumadhva, 2009. Enhancement of amygdaloid neuronal dendritic arborization by fresh leaf juice of centella asiatica (Linn) during growth spurt period in rats. Evidence-based Compl. Alt. Med., 6: 203-210. DOI: 10.1093/ecam/nem079

Mohapatra, H., D.P. Barik and S.P. Rath, 2008. In vitro regeneration of medicinal plant centella asiatica. Biol. $\quad$ Plantarum., 52: 339-342. DOI: $10.1007 / \mathrm{s} 10535-008-0069-5$

Mucimapura, S., J. Wattanathorn, S. Thongrong, K. Chaisiwamongkol and B. Sripanidkulchai, 2010. Morus alba enhanced functional recovery after sciatic nerve crush injury. Am. J. Agri. Bio. Sci., 5: 294-300. DOI: 10.3844/ajabssp.2010.294.300

Murashige, T. and F. Skoog, 1962. A revised medium for rapid growth and bio assays with tobacco tissue culture. Physiol. Plantarum., 15: 473-497. DOI: 10.1111/j.1399-3054.1962.tb08052.x

Murthy, B.N.S., S.J. Murch and P.K. Saxena, 1998. Thidiazuron: A potent regulator of in vitro plant morphogenesis. Vitro Cell Dev. Biology-Plant, 34: 267-275.

http://cat.inist.fr/?aModele $=$ afficheN\&cpsidt $=1603421$

Nath, S. and A.K. Buragohain, 2005. Establishment of callus and cell suspension cultures of centella asiatica. Biol. Plantarum., 49: 411-413. DOI: $10.1007 / \mathrm{s} 10535-005-0017-6$

Nay, M.M.T. Saw, H. Riedel, O. Kütük, K. Ravichandran and I. Smetanska, 2010. Effect of elicitors and precursors on the synthesis of anthocyanin in grape vitis vinifera cell cultures. Energy Res. J., 1: 189-192. DOI: 10.3844/ERJSP.2010.189.192

Nontaswatsri, C., S. Ruamrungsri and S. Fukai, 2008. Callus induction and plant regeneration of dianthus chinensis L. and dianthus barbatus L. via anther culture. Acta Hort., 788: 109-114. http://www.actahort.org/members/showpdf?booknr arnr $=788 \_12$

Pellegrineschi, A., R.M. Brito, S. McLean and D. Hoisington, 2004. Effect of 2, 4-dichlorophenoxyacetic acid and $\mathrm{NaCl}$ on the establishment of callus and plant regeneration in durum and bread wheat. Plant Cell. Tiss., Org., 77: 245-250. DOI: 10.1023/B:TICU.0000018389.99656.d8

Peterson, J. and J. Dwyer, 1998. Flavonoids: Dietary occurrence and biochemical activity. Nutr. Res., 18: 1995-2018. DOI: 10.1016/S0271-5317(98)00169-9
Salma, U., M.S.M. Rahman, S. Islam, N. Haque and T.A. Jubair et al., 2008. The influence of different concentration and combination on callus induction and regeneration of rauwolfia serpentine L. Benth. Pak. J. Biol. Sci., 11: 1638-1641. DOI: 10.3923/PJBS.2008.1638.1641

Shirani, S., M. Sariah, W. Zakaria and M. Maziah, 2010. Scalp induction rate responses to cytokinins on proliferating shoot-tips of banana cultivars (Musa spp.). Am. J. Agri. Bio. Sci., 5: 128-134. DOI: 10.3844/ajabssp.2010.128.134

Syamsudin, R.M. Dewi and Kusmardi, 2009. Immunomodulatory and In vivo antiplasmodial activities of propolis extracts. Am. J. Pharmacol. Toxicol., 4: 75-79. DOI: 10.3844/ajptsp.2009.75.79

Tohidi-Moghadam, H.R., A.H. Shirani-Rad, G. NourMohammadi, D. Habibi and M. Mashhadi-AkbarBoojar, 2009. Effect of super absorbent application on antioxidant enzyme activities in canola (Brassica napus L.) cultivars under water stress conditions. Am. J. Agri. Bio. Sci., 4: 215-223. DOI: 10.3844/ajabssp.2009.215.223

Whitmer, S., R. Verpoorte and C. Canel, 1998. Influence of auxins on alkaloid accumulation by a transgenic cell line of catharanthus roseus. Plant Cell. Tiss. Org., 53: 135-141. DOI: 10.1023/A:1006019620897

Wu, C.H., Y.H. Dewir, E.J. Hahn and K.Y. Paek, 2006. Optimization of culturing conditions for the production of biomass and phenolics from adventitious roots of echinacea angustifolia. J. Plant Biol., 49: 193-199. DOI: $10.1007 / \mathrm{BF} 03030532$

Wu, S.X., Y.G. Zuand M. Wu, 2003. High yield production of salidroside in the suspension culture of rhodiola sachalinensis. J. Biotechnol., 106: 33-43. DOI: $10.1016 / \mathrm{j}$.jbiotec.2003.07.009

Xu, L., U. Najeed, R. Raziuddin, W.Q. Shen and J.Y. Shou et al., 2009. Development of an efficient tissue culture protocol for callus formation and plant regeneration of wetland species Juncus effuses L. Vitro Cellular Dev. Biology-Plant, 45: 610-618. DOI: $10.1007 / \mathrm{s} 11627-009-9228-4$

Yan, M.M., C. Xu, C.H. Kim, Y.C. Um and A.A. Bah et al., 2009. Effects of explant type, culture media and growth regulators on callus induction and plant regeneration of Chinese jiaotou allium chinense. Sci. Hortic., 123: 124-128. DOI: $10.1016 /$ j.scienta.2009.07.021

Yang, J., Z.C. Gong and X. Tan, 2008. Induction of callus and extraction of alkaloid from $\mathrm{Yi} \mathrm{Mu} \mathrm{Cao}$ (leonurus heterophylus Sw.) culture. Afr. J. Biotechnol. 7: 1157-1162. http://ajol.info/index.php/ajb/article/viewFile/5863 $7 / 46971$ 
Yang, Z.S., G.D. Chen, Y.X. Li and J. Chen, 2009. Characterization of callus formation in leaf of Euphorbia helioscopia. Afr. J. Plant Sci., 3: 122-126. http://www.academicjournals.org/AJPS/PDF/Pdf20 09/Jun/Yang\%20et\%20al.pdf

Zainol, M.K., A. Abd-Hamid, S. Yusof and R. Muse, 2003. Antioxidative activity and total phenolic compounds of leaf, root and petiole of four accessions of centella asiatica L. Urban. Food Chem., 81 : 575-581. DOI: $10.1016 / \mathrm{S} 0308-8146(02) 00498-3$
Zhao, D.X., J.M. Xing, M.Y. Li, D.P. Lu and Q, 2001. Optimization of growth and jaceosidin production in callus and cell suspension cultures of saussurea medusa. Plant Cell. Tiss. Org., 67: 227-234. DOI: $10.1023 / \mathrm{A}: 1012770623153$

Zhao, L., S. Liu and S. Song, 2010. Optimization of callus induction and plant regeneration from germinating seeds of sweet sorghum (sorghum bicolor mench). Afr. J. Biotechnol., 9: 2367-2374. http://eprints.icrisat.ac.in/572/1/AfricanJBiotechnol ogy9_16_2367_2374_2010.pdf 